\title{
1 Advances in sensing ammonia from agricultural sources
}

2

3 Matías Insaustia, ${ }^{\text {b* }}$, Roger Timmis ${ }^{c}$, Rob Kinnersley $^{d}$, Mariana C. Rufino ${ }^{b}$

4

5 aINQUISUR (UNS-CONICET), Universidad Nacional del Sur, B8000CPB, Argentina

6 bLancaster Environment Centre, Lancaster University, LA1 4YQ, United Kingdom

7 'Environment Agency, Lancaster University, Lancaster, LA1 4YQ, United Kingdom

dEnvironment Agency, Evidence Directorate, Deanery Road, Bristol, BS1 5AH, United

$9 \quad$ Kingdom

10

*corresponding author, email: matiasi@conicet.gov.ar

12 
Reducing ammonia emissions is one of the most difficult challenges for environmental regulators around the world. About $90 \%$ of ammonia in the atmosphere comes from agricultural sources, so that improving farm practices in order to reduce these emissions is a priority. Airborne ammonia is the key precursor for particulate matter (PM2.5) that impairs human health, and ammonia can contribute to excess nitrogen that causes eutrophication in water and biodiversity loss in plant ecosystems. Reductions in excess nitrogen ( $\mathrm{N}$ ) from ammonia are needed so that farms use $\mathrm{N}$ resources more efficiently and avoid unnecessary developments are required to identify sources, individual contributions, to evaluate the effectiveness of controls, to monitor progress towards emission-reduction targets, and to develop incentives for behavioural change. There is specifically a need for sensitive, selective, robust and user-friendly sensors to monitor ammonia from livestock production and fertiliser application. Most currently-available sensors need specialists to set up, calibrate and maintain them, which creates issues with staffing and costs when monitoring advances in monitoring airborne ammonia in agricultural areas. Selecting the right method of monitoring for each agricultural activity will provide critical data to identify and implement appropriate ammonia controls. Recent developments in chemo-resistive materials allow electrochemical sensing at room temperature, and new spectroscopic methods are sensitive enough to determine low concentrations in the order of parts per billion. However, these new methods still compromise selectivity and sensitivity due to the presence of ambient dust and other interferences, and are not yet suitable to be applied in agricultural monitoring. This review considers how ammonia measurements are made and applied, including the need for sensors that are suitable for routine monitoring by non-specialists. The review evaluates how monitoring information can be used for policies and regulations to mitigate ammonia emissions. The increasing concerns about ammonia emissions and the particular needs 
from the agriculture sector are addressed, giving an overview of the state-of-the-art and an outlook on future developments.

Keywords: Ammonia, Sensors, Nitrogen losses, Livestock production, Fertiliser Application.

\section{Introduction}

In most developed countries, the dominant source of ammonia $\left(\mathrm{NH}_{3}\right)$ emissions is the agroindustry . Efforts to mitigate these emissions must therefore focus on improving those agricultural activities that are important contributors - such as livestock feeding and housing, excreta management, and fertilisation practices. To develop better agricultural practices it is critical to know which sources contribute to these emissions, when, and by how much. Ammonia measurements are primarily needed to understand emission rates, the effectiveness of control measures, the impact of atmospheric processes and the outcomes of exposure. Many types of sensors and devices for measuring $\mathrm{NH}_{3}$ are commercially available, and some promising new developments will be discussed in this paper. However, most of the current devices are relatively specialised, costly or difficult to apply in "real world" farming situations, so they are not readily used for day-to-day monitoring by non-specialist practitioners. Also, there are only a few sensors that have enough sensitivity to measure $\mathrm{NH}_{3}$ emissions from fertilised soils, such as those using mid-ultraviolet absorption spectroscopy, photoacoustic spectroscopy or the recent artificial nose with fluorescence detection. $\mathrm{NH}_{3}$ measurements are needed to improve agricultural efficiency, and to contribute to a better quality of life - because excess concentrations of $\mathrm{NH}_{3}$ lead to adverse impacts on human health and on the health and diversity of ecosystems. Reductions in $\mathrm{NH}_{3}$ emissions would support more efficient food production that uses fewer resources, and so would reduce the environmental impacts of food supply chains. Availability of simple, reliable and low cost measurements and procedures will help developing an improved understanding of $\mathrm{NH}_{3}$ emissions which is important for:

i) Agricultural producers: reduced $\mathrm{NH}_{3}$ emission will generate savings in nitrogen fertilisers . More efficient use of crude protein in animal feed reduces $\mathrm{N}$ excretion, 
and these emission reductions could attract farm payments if they are linked to environmental improvements.

ii) Researchers: to develop new and more suitable technologies to reduce emissions and solve problems for the agroindustry and society.

iii) Wider society and the economy: to decrease the combined cost for human health and biodiversity from excess $\mathrm{NH}_{3}$, which is estimated to be 4-30 euros per $\mathrm{kg} \mathrm{N}$ pollution in 2011 .

iv) Regulators: to target control measures effectively onto culpable sources, and to evaluate source performance and the effectiveness of controls.

v) Policymakers and government: monitoring $\mathrm{NH}_{3}$ emissions is required to meet international emission reduction targets.

\section{Ammonia in the environment}

The distinct smell of ammonia is often noticed in rural parts of developed countries with highdensity livestock farming, especially near intensive pig, poultry or cattle facilities or after liquid manure has been spread on the land. $\mathrm{NH}_{3}$ is a colourless with a very perceptible odour, even at very low concentrations. It is a common gas that is released in the natural environment from decomposing organic material and animal waste. In the agricultural industry, $\mathrm{NH}_{3}$ can be used as a fertiliser in the pure gas form of anhydrous $\mathrm{NH}_{3}$, but it is also widely used to make nitrogen-based fertilisers such as urea, urea-ammonium nitrate, ammonium sulfate, ammonium nitrate and diammonium phosphate. $\mathrm{NH}_{3}$ is also used as a refrigerant, and in the manufacture of plastics, explosives, textiles, pesticides, dyes and other chemicals. Although $\mathrm{NH}_{3}$ is commonly present in nature and widely used in industry, it is classified as an extremely hazardous substance because it is both caustic and flammable - The United States Environmental Protection Agency has classified $\mathrm{NH}_{3}$ as a hazardous substance because of its toxicity to humans, and has set a maximum safe level of $25 \mathrm{ppm}$ for long term exposure ( 8 hours) and of $35 \mathrm{ppm}$ for short term exposure (15 min). For livestock, exposure to $25 \mathrm{ppm}$ of $\mathrm{NH}_{3}$ can adversely affect weight gain, feed conversion and mortality rates. Several institutions regulate exposure and peak instantaneous 
concentrations, but there are no regulations for $\mathrm{NH}_{3}$ emission rates. The 'Environmental

112 Permitting Regulations' relate to ammonia emissions, which set a limit for large livestock facilities on the number of animals that can be kept near a sensitive habitat. Critical level of ammonia concentration cannot be exceeded, and these concentrations are calculated based on accepted emission factors for livestock for different production systems. Another relevant piece of legislation is the National Emission Ceilings Directive (NECD), which sets targets for maximum annual emissions from individual European countries. There is also the Gothenburg Protocol of The United Nations Economic Commission for Europe (UNECE) which is an international agreement to abate acidification, eutrophication and ground-level ozone, that aims to reduce emissions of several pollutants including $\mathrm{NH}_{3}$.

Livestock excreta and fertilisers are major sources of ammonia. Large amounts of $\mathrm{NH}_{3}$ are released from excreta immediately after deposition and during decomposition. Livestock are often fed high-protein feeds containing $\mathrm{N}$ to ensure that their nutritional requirements are met, but the $\mathrm{N}$ that is not converted to animal protein is excreted in the urine and the faeces. Once the $\mathrm{N}$ compounds are in the faeces or urine, enzyme reactions or microbial activity quickly release $\mathrm{NH}_{3}$ to the atmosphere. This is because the urea produced and excreted by mammals is rapidly converted to $\mathrm{NH}_{3}$ gas by the urease enzyme. In the case of poultry, it is uric acid that is excreted and mostly converted to urea, and then to $\mathrm{NH}_{3}$. There are several technologies that can be implemented to reduce $\mathrm{NH}_{3}$ emissions by reducing the availability of both precursors (urea and the urease enzyme) such as controlling the contents of livestock diets or using urease inhibitors such as is N-(n-Butyl)-thiophosphoric triamide (NBPT) . Another control option is to reduce urea hydrolysis by separating the urea and faeces . Key methods to control ammonia emissions from animal excreta are to keep it as dry as possible (i.e. by using indirect heating or heat exchangers); to keep it covered (e.g. floating covers for slurry stores and lagoons); to acidify it; and to avoid adverse weather conditions such as high temperatures, high humidity and adverse wind direction when manure is injected into the soil. The other large source of $\mathrm{NH}_{3}$ gas is the application of $\mathrm{N}$ 
fertilisers, which represents a significant fraction (23\%) of $\mathrm{NH}_{3}$ emissions (Figure 1, data from the UK Code COGAP). All fertilisers containing ammonium $\left(\mathrm{NH}_{4}^{+}\right)$are subject to volatile losses and the $\mathrm{NH}_{3}$ emissions is largely controlled by $\mathrm{pH}$. Precision agriculture can help adjusting fertiliser rates to reduce excess $\mathrm{N}$ application and hence losses by volatilization or run-off.

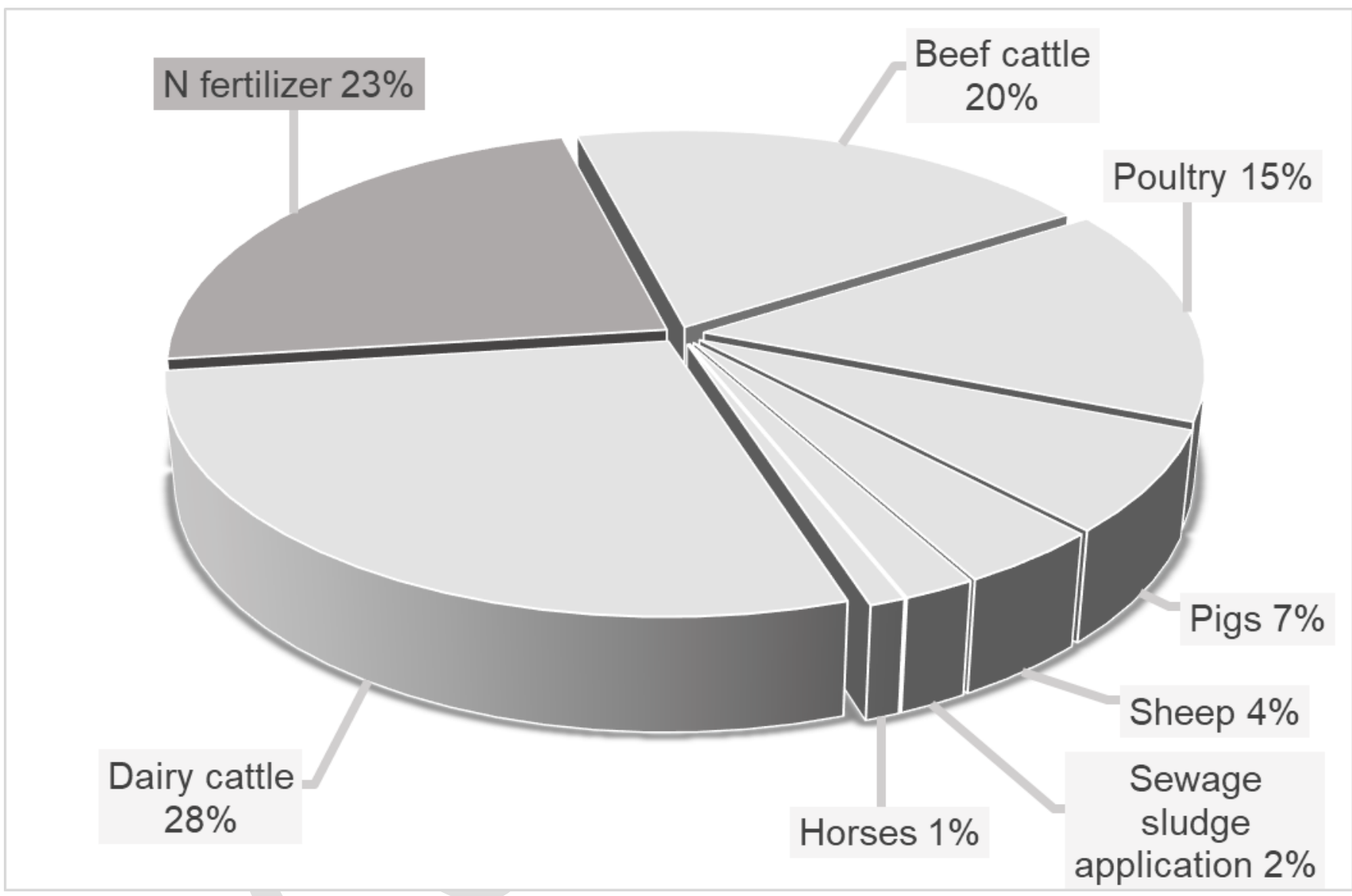

Figure 1: Agricultural $\mathrm{NH}_{3}$ emissions in the UK by livestock (light grey) and fertiliser category

Presently, $\mathrm{NH}_{3}$ stands out as the air pollutant whose ambient concentrations are not decreasing rapidly, and occasionally increase slightly. Similarly, emissions of $\mathrm{NH}_{3}$ during the last 3 decades have reduced much more slowly than those of other major air pollutants such as $\mathrm{NO}_{x}, \mathrm{SO}_{2}$ and non-methane volatile organic compounds. A recent study shows that there are numerous $\mathrm{NH}_{3}$ hotspots and unknown sources unidentified around the world. Areas with high beef cattle density are reported to produce an average of $50 \mu \mathrm{g} \mathrm{N} \mathrm{m}^{-2} \mathrm{~s}^{-1}\left(85 \mathrm{~g}_{\text {animal }}{ }^{-1}\right.$ 
day $^{-1}$ ). The Po Valley in northern Italy is considered the region in Europe with the highest intensity of $\mathrm{NH}_{3}$ emissions, which can reach maximum values close to $250 \mu \mathrm{g} \mathrm{m}^{-2} \mathrm{~s}^{-1}$ during the season of manure application. After urea application to soils, $\mathrm{NH}_{3}$ emissions can reach an peak of about $5 \mu \mathrm{g} \mathrm{m}^{-2} \mathrm{~s}^{-1}$ around midday if there is no rain. In order to address the environmental burden of $\mathrm{NH}_{3}$ emissions and to design management strategies, it is necessary to distinguish the main sources of agricultural $\mathrm{NH}_{3}$, because $88-94 \%$ of $\mathrm{NH}_{3}$ in the troposphere comes from farming practices , of which $65-71 \%$ is from livestock and $16-23 \%$ from fertiliser application. There are several options to mitigate $\mathrm{NH}_{3}$ emissions and increased efforts are needed to lower concentrations to safer levels. To support the implementation of policies and changes to farming practices are effective, there is a need to monitor emissions and ambient levels of $\mathrm{NH}_{3}$. For that purpose, a transformative improvement in monitoring technology is required to get real-world data from multiple sites and activities.

\section{Impacts of ammonia emissions}

Ammonia in the atmosphere has become a concern for environmental and health agencies for two main reasons: because of excess $\mathrm{N}$ deposition and because $\mathrm{NH}_{3}$ is a precursor of fine particulate matter, both of which can impair human health. $\mathrm{NH}_{3}$ is an alkaline compound, and when released into the air it is rapidly adsorbed to surfaces and significant deposition (up to $20 \%$ ) may occur over distances ranging from a few hundreds of meters of the source to hundreds of miles. The remaining atmospheric $\mathrm{NH}_{3}$ can rapidly react with acid gas compounds (such as $\mathrm{SO}_{2}$ and $\mathrm{NO}_{x}$ from vehicular and industrial combustion processes) to form very small secondary aerosol particles. This fine particulate matter has an aerodynamic equivalent diameter of $<2.5$ microns (referred to as PM2.5), having a lifespan of up to 2 weeks and contributing to atmospheric haze and low visibility $\mathrm{NH}_{3}$ is transported by wind and deposited not far away from the source where it can promote plant growth in areas where $\mathrm{N}$ was previously a limiting factor. An example of this phenomenon is the eutrophication in catchments, including algal blooms that impair water quality and can harm 
ecosystems and people. Dry $\mathrm{N}$ deposition is a continuous process where the gases and aerosols from the atmosphere are transferred to the surface by atmospheric turbulence and diffusion, whereas wet deposition is the intermittent removal of chemical species from the atmosphere by precipitation. Airborne $\mathrm{NH}_{3}$ concentrations reflect and approach a dynamic equilibrium between deposition and re-emission, an ongoing exchange between the surface and the atmosphere. Changes in plant species composition have been observed in natural ecosystems where high $\mathrm{N}$ deposition occurs. There is a loss of biodiversity because $\mathrm{N}$ intolerant plants become depleted and $\mathrm{N}$-tolerant plants become dominant. An example of this effect is the direct damage to sensitive vegetation such as lichens and bryophytes that occur even at very low $\mathrm{NH}_{3}$ concentrations of around $1 \mu \mathrm{g} \mathrm{NH} \mathrm{NH}_{3}^{-3}$. Moreover, the deposition of $\mathrm{N}$ onto soils with a low buffering capacity can result in soil acidification and consequently basic cation depletion. Harm to human beings is caused by the fine particles that are inhaled deeply into the lungs and impair respiratory function and cardiovascular health . In addition, high concentrations (25 ppm) of atmospheric $\mathrm{NH}_{3}$, as it is an irritant compound, have a negative effect on animal production in confined buildings and farm workers should avoid prolonged exposure.

\section{Detection and quantification of ammonia}

We review here the methods currently available to measure $\mathrm{NH}_{3}$ and discuss some of the previous and significant developments in the field. The instant value of $\mathrm{NH}_{3}$ concentration in the air, a measure that the currently available sensors usually provide, is only useful to meet the requirements of regulations in different activities. For some farming activities, regulators require instantaneous measurements of $\mathrm{NH}_{3}$ concentrations, but these measurements have to be used in modelling platforms with other data to estimate wider emissions and impacts of airborne ammonia. To be able to manage emissions from agriculture there is a need for sensors to identify and quantify different sources, including point, area and volume sources, and to identify major contributors. Monitoring programmes should provide data on $\mathrm{NH}_{3}$ concentrations across a range of different scales and environments linking sources and 
receptors. At present a major challenge is to detect the low concentrations occurring in the troposphere $(0.3-6 \mathrm{ppb})$. Moreover, when the aim is to provide meso-scale and regional patterns, in traditional monitoring schemes, low-frequency (weekly, monthly) sampling is usually selected, which presents the challenge of delivering data over long periods. Most of the available sensors require a qualified operator to set up, calibrate, maintain and decommission the measurements, which creates issues with staffing and costs when monitoring large areas or when there is a need for high frequency sampling. One of the biggest challenges is to design monitoring that can be used successfully by non-specialists e.g. farmers. A range of monitoring techniques is required that covers different levels of complexity and detail e.g. cheap and easy-to-deploy methods that non-specialists can use for basic reconnaissance and scoping of sources, and more sophisticated methods can be used to identify individual source contributions and performance in complex or specialised studies. Quantifying $\mathrm{NH}_{3}$ gas emissions needs devices that measure concentrations but also modelling methods to scale concentrations and to calculate emission rates. Also, important critical information is needed to achieve accurate estimations of emission rates, like information on livestock housing facilities, feeds, temperature, wind speed, ventilation rates, among others. Several modelling approaches have been used to estimate $\mathrm{NH}_{3}$ emission rates, and in order to obtain robust estimates they must take account of variables like wind speed, humidity and air temperature at different heights - which may be measured or derived from numerical weather prediction models. There are particular challenges when measuring $\mathrm{NH}_{3}$ at low concentrations, because the polarity and geometry of the molecule make it highly soluble in water so it tends to adsorb onto surfaces such as air sampling tubes, which can result in significant errors when concentrations are low .

For review purposes, the range of sensors available can be classified by different aspects, such as cost, temporal resolution, and level of automation. In this review, sensors were classified by the analytical technique used to detect $\mathrm{NH}_{3}$ molecules. The sensors covered are only those considered suitable for agricultural applications. These sensors need to be 
238 portable, and be selective for $\mathrm{NH}_{3}$ so that measurements are not compromised by 239 interference from other ambient chemicals. They also need to have a wide range of 240 operation to measure concentrations found in farming and sensitive ecosystem situations, 241 including the low concentrations that occur in some environments. Some sensors are 242 suitable for measurements in livestock housing and manure storage situations, whereas 243 others are suitable for measuring lower concentrations of $\mathrm{NH}_{3}$ from fields (Figure 2 and 244 Table 1). As shown in Table 2, only high-cost equipment (e.g. chemiluminescent or 245 photoacoustic, cost $>\$ 25.000$ ) is suitable for directly measuring low concentrationsof $\mathrm{NH}_{3}$ $246(<0.1 \mathrm{ppm})$. Lower-cost sensors (electrochemical types, cost $\$ 500-\$ 2000)$ are generally 247 designed for higher-concentration situations e.g. for $\mathrm{NH}_{3}$ leak detection ( $\left.>1 \mathrm{ppm}\right)$. An 248 alternative to high-cost sensors is the use of passive and active samplers that can 249 accumulate $\mathrm{NH}_{3}$ over long periods (usually between 1 week and 1 month), which enables them to detect low time-averaged concentrations. Moreover, an interesting new device can provide information about the location of a source without needing a power supply. This is a

252 directional passive air sampler which resolves concentrations into $12 \times 30^{\circ}$ sectors, and combines a static carousel containing passive samplers with a rotatable inlet that aligns with the wind . Passive samplers tend to be cheaper and easier to deploy than active (powered) samplers, but they provide lower temporal resolution and still need laboratory analysis to obtain an average value of $\mathrm{NH}_{3}$ concentration. 


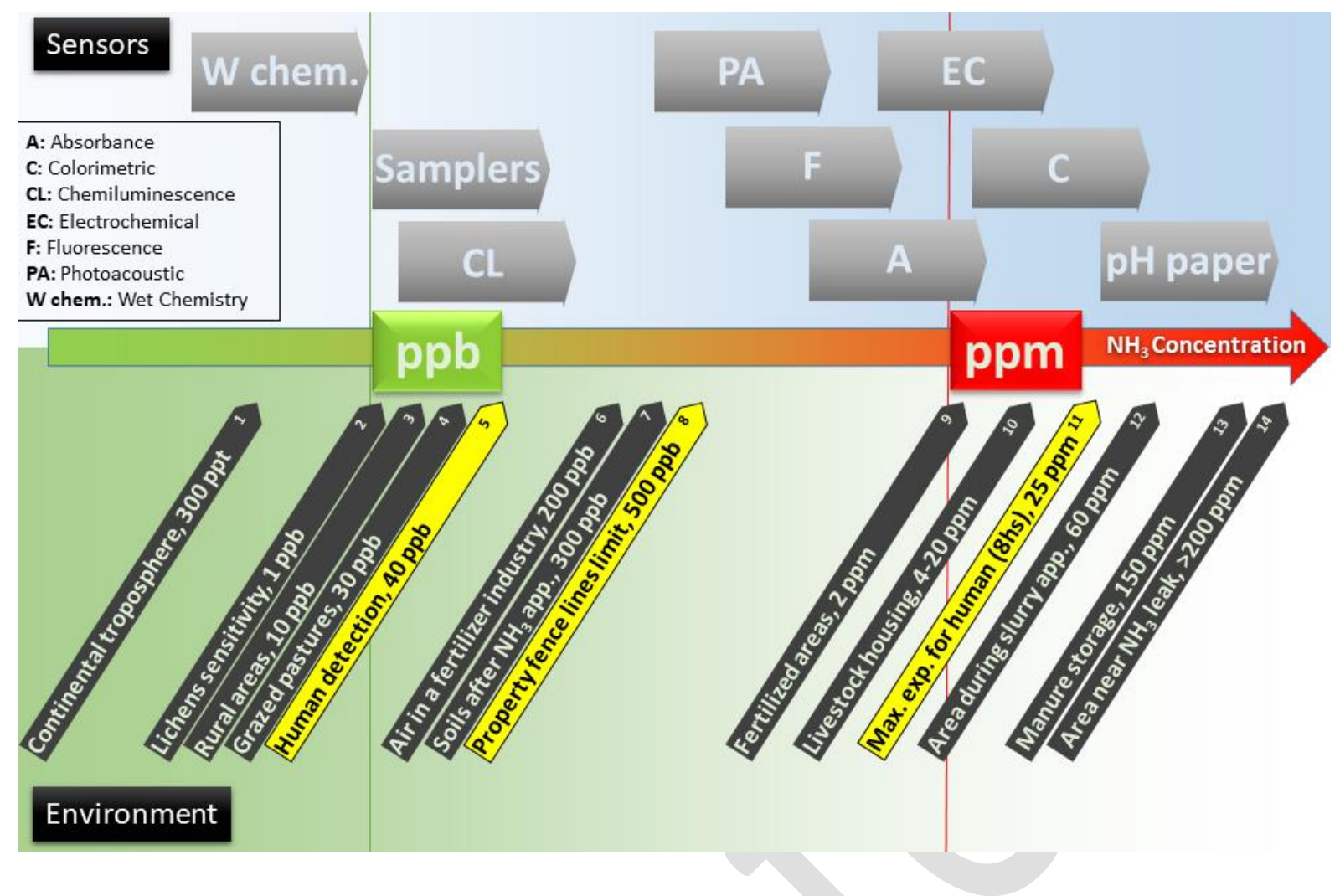

259 Figure 2. Reported $\mathrm{NH}_{3}$ concentrations in different environments and sensor techniques for 260 different concentration; see Table 1 for details. The yellow arrows indicate established limits 261 for $\mathrm{NH}_{3}$ in air. 1) , 2) , 3), 4), 5), 6), 7), 8), 9) , 10) , 11) , 12) , 13) , 14). 
Typical concentrations are shown for different source and receptor situations, ranging from remote background locations to near-source storage and leakage situations

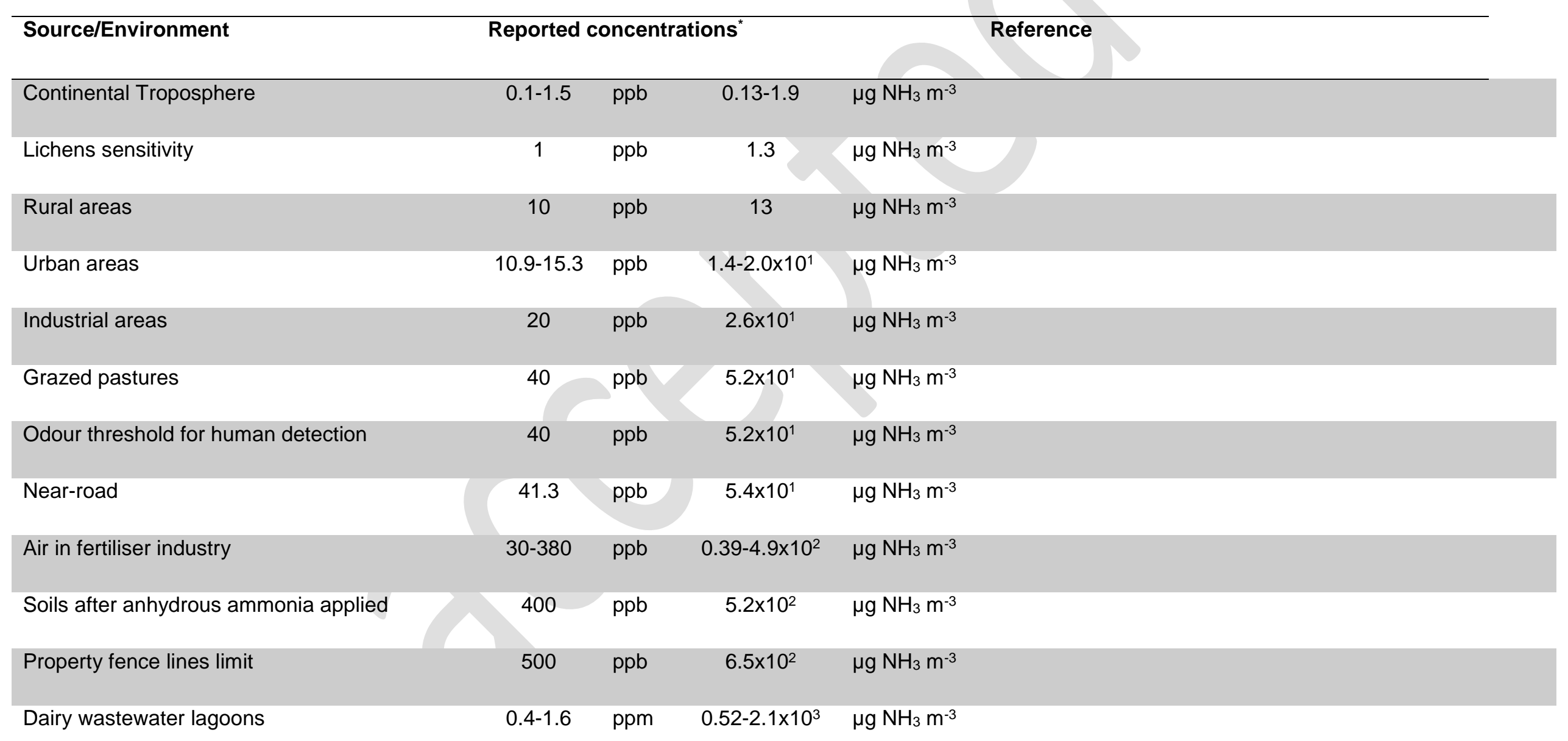




\begin{tabular}{|c|c|c|c|c|}
\hline $\begin{array}{l}\text { Areas after manure or synthetic fertilise } \\
\text { application }\end{array}$ & $0.01-5$ & ppm & $0.01-6.5 \times 10^{3}$ & $\mu \mathrm{g} \mathrm{NH} \mathrm{Nm}^{-3}$ \\
\hline Beef cattle housing & 4 & ppm & $5.2 \times 10^{3}$ & $\mu \mathrm{g} \mathrm{NH} \mathrm{N}^{-3}$ \\
\hline Dairy Housing & $0.8-10$ & ppm & $0.1-1.3 \times 10^{4}$ & $\mu \mathrm{g} \mathrm{NH} \mathrm{m}^{-3}$ \\
\hline Hog housing & $5-28$ & ppm & $0.7-3.6 \times 10^{4}$ & $\mu \mathrm{g} \mathrm{NH} \mathrm{N}^{-3}$ \\
\hline Poultry houses & 20 & ppm & $2.6 \times 10^{4}$ & $\mu \mathrm{g} \mathrm{NH} \mathrm{N}^{-3}$ \\
\hline Maximum exposure for humans (8hs) & 25 & ppm & $3.3 \times 10^{4}$ & $\mu \mathrm{g} \mathrm{NH} \mathrm{N}^{-3}$ \\
\hline Area during slurry application & 60 & ppm & $7.8 \times 10^{4}$ & $\mu \mathrm{g} \mathrm{NH} \mathrm{m}^{-3}$ \\
\hline Manure storage & 150 & ppm & $2.0 \times 10^{5}$ & $\mu \mathrm{g} \mathrm{NH} \mathrm{m}^{-3}$ \\
\hline Area near an ammonia leak & $100-600$ & ppm & $1.3-7.8 \times 10^{5}$ & $\mu \mathrm{g} \mathrm{NH} \mathrm{Nm}^{-3}$ \\
\hline *Transformation rate of $\mathrm{NH}_{3}$ concentrations: & & & & \\
\hline
\end{tabular}


266 Table 2. Reported ammonia sensors and their measured concentrations. The table is separated in commonly reported concentration for each

267 class and outstanding sensors.

\begin{tabular}{|c|c|c|c|c|c|c|c|c|}
\hline \multirow[t]{2}{*}{$\begin{array}{l}\text { Technique or } \\
\text { method based }\end{array}$} & \multicolumn{2}{|c|}{$\begin{array}{c}\text { Usual } \\
\text { concentration }\end{array}$} & \multirow[t]{2}{*}{$\begin{array}{l}\text { Sample } \\
\text { rate }\end{array}$} & \multicolumn{2}{|c|}{$\begin{array}{l}\text { Concentration of } \\
\text { selected sensors }\end{array}$} & \multirow[t]{2}{*}{$\begin{array}{l}\text { Sample } \\
\text { rate }\end{array}$} & \multirow[t]{2}{*}{ Use } & \multirow[t]{2}{*}{ Reference } \\
\hline & LOD & Range & & LOD & Range & & & \\
\hline Wet chemistry & $\begin{array}{r}0.1 \\
\mathrm{ppb}\end{array}$ & $\begin{array}{l}0.1 \mathrm{ppb} \\
-1000 \\
\text { ppm }\end{array}$ & $>\min$ & $\begin{array}{l}0.58 \\
\mathrm{ppt}\end{array}$ & $\begin{array}{l}5.5-30 \\
\text { ppt }\end{array}$ & - & $\begin{array}{l}\mathrm{NH}_{3} \text { concentrations below ppb levels and } \\
\text { reference methods. }\end{array}$ & \\
\hline $\begin{array}{l}\text { Chemiluminesce } \\
\text { nce }\end{array}$ & $\begin{array}{l}0.2 \\
1 \\
\mathrm{ppm}\end{array}$ & $\begin{array}{l}0.25-100 \\
\mathrm{ppm}\end{array}$ & $>\min$. & $\begin{array}{l}60 \\
\mathrm{ppb}\end{array}$ & $\begin{array}{l}0.31-59.6 \\
\mathrm{ppm}\end{array}$ & - & $\begin{array}{l}\text { Field instrumentation for low } \mathrm{ppb} \mathrm{NH}_{3} \\
\text { concentrations }\end{array}$ & \\
\hline $\begin{array}{l}\text { Passive } \\
\text { Collectors }\end{array}$ & $\begin{array}{l}0.2 \\
\mathrm{ppb}\end{array}$ & $\begin{array}{l}0.2-100 \\
\mathrm{ppb}\end{array}$ & $\begin{array}{l}>\text { hours } \\
- \\
\text { months. }\end{array}$ & - & $>0.2 \mathrm{ppb}$ & - & $\begin{array}{l}\mathrm{NH}_{3} \text { diffusion tubes are useful for providing } \\
\text { long-term estimates. }\end{array}$ & \\
\hline Photoacoustic & $\begin{array}{l}0.3 \\
\mathrm{ppm}\end{array}$ & $\begin{array}{l}0.3-10 \\
\mathrm{ppm}\end{array}$ & $>$ sec. & $\begin{array}{l}0.1 \\
\mathrm{ppb}\end{array}$ & $\begin{array}{l}0.1 \mathrm{ppb}- \\
3 \mathrm{ppm}\end{array}$ & $5 \mathrm{~L} / \mathrm{min}$ & $\begin{array}{l}\text { Laboratory instrumentation for } \mathrm{NH}_{3} \\
\text { concentrations below ppm levels }\end{array}$ & \\
\hline Fluorescence & 0.5 & $0.5-50$ & $>\min$ & 30 & $30-380$ & 15 & Laboratory instrumentation for $\mathrm{NH}_{3}$ & \\
\hline
\end{tabular}




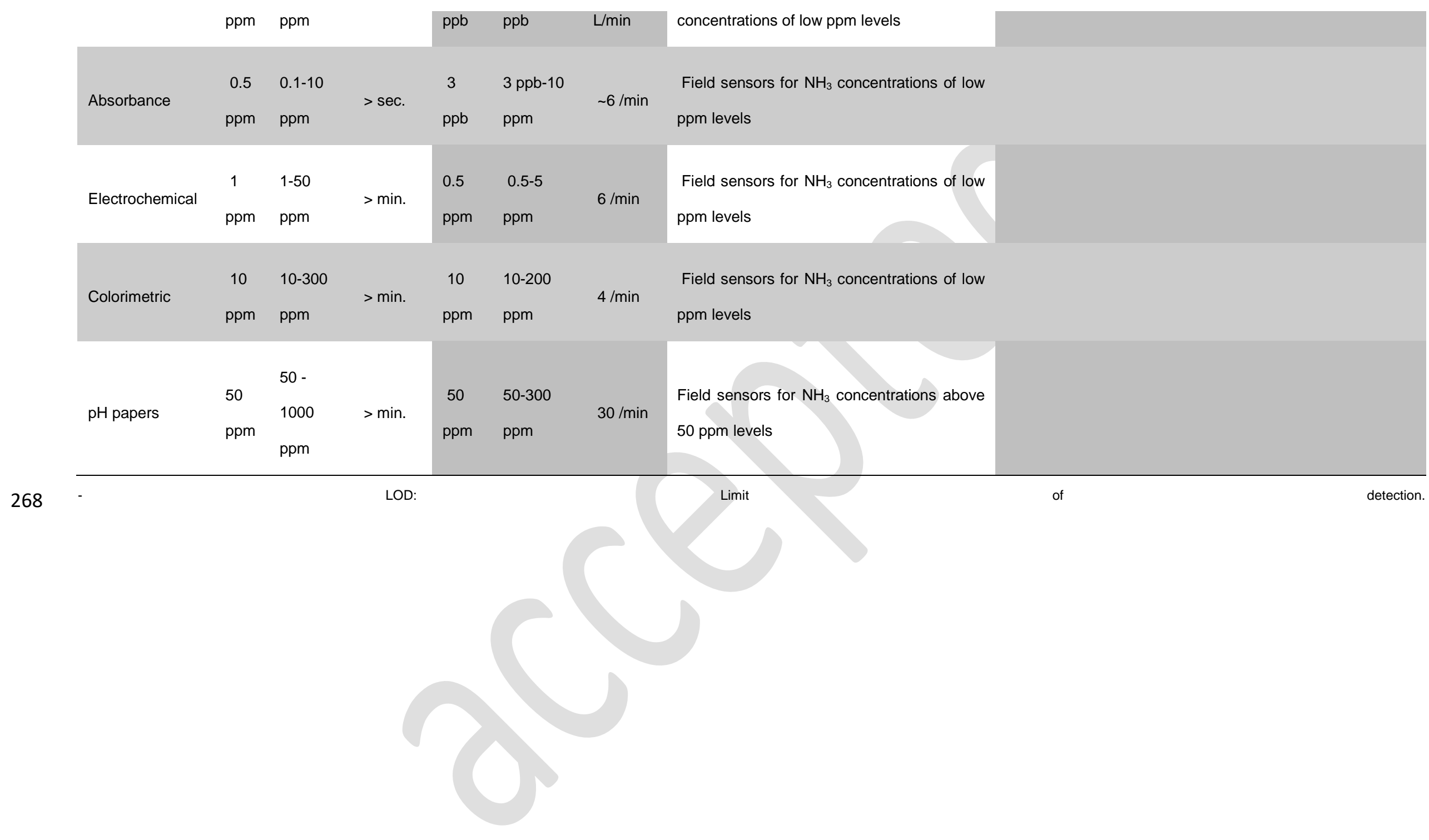




\subsection{Types of Sensors}

Based on the main system used to detect ammonia, there are two broad types of sensors: electrochemical and spectrometric. There are also two main strategies for obtaining an analytical signal from the $\mathrm{NH}_{3}$ molecule: direct measurement of $\mathrm{NH}_{3}$ itself, or indirect measurement of a compound that derives from a reaction with $\mathrm{NH}_{3}$. Most methods described here rely on collecting gaseous $\mathrm{NH}_{3}$ in an acidic medium and then measuring the concentration. There is a need to distinguish between gaseous and particulate ammonia. The volume of air passed through a sampler is recorded and the $\mathrm{NH}_{3}$ concentration in the air is calculated.

\subsubsection{Electrochemical sensors}

The principle of electrochemical sensors involves detecting the change in an electrical signal (resistance, potential, current) caused by adsorption of $\mathrm{NH}_{3}$ into different materials. Voltametric or potentiometric determinations were developed typically to measure $\mathrm{NH}_{3}$ in aqueous samples, for which the detection limits ( 1-100 ppm) are much higher than for air samples . Although amperometric $\mathrm{NH}_{3}$ sensors offer high sensitivity, they are characterised by low selectivity because the $\mathrm{NH}_{3}$ signal cannot be readily distinguished from interfering signals due to other compounds that are present. Because of this interference, these types of sensors are not suitable for agricultural applications and so are not discussed further. Generally, those studies that present new developments in electrochemical sensing are conducted by material scientists, which could explain why their application in agriculture is rarely discussed. In addition, the concentrations investigated in these studies (1-10,000 ppm) tend to be higher than the concentrations applicable to agricultural $\mathrm{NH}_{3}$ situations (0.01-100 ppm). Nevertheless, the chemical alarm systems used to signal potentially unsafe levels of $\mathrm{NH}_{3}$ in housing facilities do not require very sensitive sensors, so that small and low-power electronic devices are feasible in these situations. Overall, semiconductor and metal-oxide gas sensors seem best-suited for these chemical alarm applications . 
297 Several new materials have been developed which can change their electrical conductivity

298 as a function of the $\mathrm{NH}_{3}$ concentration in air. Chemi-resistive materials have been used to 299 detect a number of oxidizing or reducing gases such as $\mathrm{NH}_{3}$, based on the charge transfer that can occur between the sensing element and the redox gas. Typically these detectors incorporate semiconductors that can be categorized as metal oxide, conductive polymers, or combinations of metal nanoparticles and conductive polymers that result in promising composite materials. Metal oxides-based $\mathrm{NH}_{3}$ sensors have shown good performance compared to carbon materials, and are competitive in analytical performance in relation to conductive polymers. The main disadvantage of metal-oxide-based technologies is the requirement for activation energy to convert the low conductivity of the materials into semiconductors . In metal-oxide-based sensors, the activation energy is usually supplied by using temperatures above $200^{\circ} \mathrm{C}$, while conductive polymers are activated through a "doping" synthesis that generates delocalized charges in the sensing element .

In recent decades, polyaniline-based materials have emerged as the preferred choice among polymer-based sensor materials, because of their cost-effectiveness, ease-ofpreparation, and superior sensing performance. Most up-to-date developments have improved stability and repeatability by combining polyaniline with other $\mathrm{NH}_{3}$-sensing materials, including combinations of polyaniline nanocomposites with metal oxides, graphene, carbon nanotubes, and other carbon nanomaterials. These developments allow material-based sensors are that they require regular maintenance and lack sensitivity and selectivity. For example, conducting polymers need regular regeneration to prevent loss of sensitivity . Most of these developments are not suitable for the agricultural environment where other redox gases are present $\left(\mathrm{N}_{2} \mathrm{O}, \mathrm{NO}_{2}, \mathrm{H}_{2} \mathrm{~S}\right.$ and $\left.\mathrm{CH}_{4}\right)$. Moreover, most of these 
sensors provide only first order data, reading only one signal value per sample, so no multivariate calibration could be applied to resolve interferences . In addition, there is a need to use non-linear regression models, which adds an extra layer of complexity to these electrochemical determinations. A few minutes per sample is needed to achieve measurements in the order of several ppm which is a high concentration for most agricultural purposes, except for alarm systems in livestock housing facilities. More complex methodologies could be used to address the problem of sensitivity. For example, Timmer et al. (2004) used miniaturization and pre-concentration by membranes and an acid trap to reach the required concentration levels $(\mathrm{ppb})$. Another approach that addresses selectivity is the use of indirect measurements of electrolyte conductivity detection. However, these methods seem to be unsuitable for long term sensing in dusty environments such as agricultural facilities, because their membranes and filters get clogged easily.

\subsubsection{Spectrometry based-sensors}

Optical devices based on spectrometry can meet stringent requirements for sensing, such as strong resistance to electromagnetic noise, high stability, low power consumption, and compatibility with explosive environments.

\subsubsection{Absorbance-based and colorimetric sensors}

The most common absorbance-based and colorimetric sensors involve direct measurements using long-path instruments and $\mathrm{NH}_{3}$-derived compounds, and indirect measurements of changes in $\mathrm{pH}$. The methods have a broad range of applications, and sensor selection depends mainly on the $\mathrm{NH}_{3}$ concentrations to be measured. The various methods cover a calibration range between 1 and $18,000 \mathrm{ppm}$ of $\mathrm{NH}_{3}$, and one study reports a limit of detection of $1 \mathrm{ppb}_{v} \mathrm{NH}_{3}$. Continuous monitoring over large areas or long paths can require low detection limits, and absorbance-based sensors seem to be the best option for these situations (See Table 2). Direct measurements can be done with open-path sensors at infrared (IR) or ultra-violet (UV) wavelengths. The methods can be used to integrate $\mathrm{NH}_{3}$ 
concentrations over several metres of air path up to 120 meters. Another method involving a

354 long optical path is cavity-ringdown spectroscopy which has been used successfully to identify $\mathrm{NH}_{3}$ emission sources, and when used with real-time data it can explain the correlation between concentrations of $\mathrm{NH}_{3}$ and other precursor gases for $\mathrm{PM}_{2.5}$ in urban air . The main disadvantages of the methods are that the initial costs for equipment and set up are high, that qualified personnel are needed to deploy and maintain the sensors, and that interferences from dust, water vapour and other gases (e.g. $\mathrm{NO}_{x}, \mathrm{CO}_{2}, \mathrm{O}_{2}$, etc.) commonly occur in agricultural environments. Invalid data from long-path instruments due to dust or laser reflector alignment issues could be avoided using the latest chemometrics approaches that can predict values with uncalibrated interferences. Moreover, miniaturized systems could solve the problem of needing large sample volumes for absorption spectroscopy, or they could enhance the absorption signal by using specific and very sensitive colour reactions that are already available .

Chemicals for deriving $\mathrm{NH}_{3}$ concentrations can be held on a variety of surfaces. The most commonly used methods for deriving $\mathrm{NH}_{3}$ are the Berthelot, Nessler and pyridine-pyrazole reactions, or their modifications. There are two commonly used arrangements that use colour changes to infer a sample gas concentration. One arrangement uses gas tube samplers that are coated inside with colour-change reagent, and are attached to a hand pump that sucks a pre-defined volume of air per stroke. Tubes are available with different measurement ranges e.g. a range of $0.25-30$ ppm is suitable for $\mathrm{NH}_{3}$ in livestock buildings . However, the sensitivity of the tubes is generally too low (>2 ppm) for measuring outdoor $\mathrm{NH}_{3}$ concentrations. The second arrangement uses a chemcassette system where a coil of paper embedded with chemicals is coupled to a measuring device. The paper acts as both a sampling medium, and as an analysis facility for detecting and measuring nanogram amounts of the target gas. These devices use a small length of paper tape per sample, allowing scheduled automatic measurements. On exposure to the target gas, the tape changes colour in direct proportion to the sample gas concentration, and a photo-optical 
system measures the colour intensity change from which the sampled gas concentration is determined .

Other thin-films samplers are reported in the literature but they are still not widely used. An example is the change in optical absorption of a thin dye-doped nanostructure polypyrrole film . Another sensor uses polyaniline deposited on the surface of a polyethylene tube . Also, there are non-specific sensors available like $\mathrm{pH}$ papers that measure indirectly the presence of $\mathrm{NH}_{3}$ in air. This method provides inexpensive in situ records for estimating $\mathrm{NH}_{3}$ concentrations by matching the colour change against a calibrated chart. Other sensors use patterns of different dyes to obtain values of $\mathrm{NH}_{3}$ and to discriminate different interferences like $\mathrm{SO}_{2}, \mathrm{Cl}_{2}, \mathrm{CO}_{2}$ or volatile amines. Chemometrics analysis is used for multivariate calibration when several dyes are used at the same time. Because these indirect methods have low sensitivity and precision, they could be suitable for preliminary and rapid analysis in high concentration environments like slurry lagoons and housing facilities.

\subsubsection{Fluorescence-based sensors}

Fluorescence is not frequently used to measure air quality in agricultural situations because few relevant compounds fluoresce, compared to those that absorb radiation. However, there is a growing interest in replacing conventional organic dyes with stable semiconductor or carbon-based photo-luminescent nanomaterials for fluorescence-based sensing. Fluorescence sensors offer relatively high sensitivity ( 50 ppb), easier design strategies, lower cost, and higher portability. Photo-luminescent carbon dots (CDs) are better than semiconductor nanomaterials in terms of their high biocompatibility, low toxicity and lower cost . To date, fluorescent CDs have been successfully exploited in a wide range of applications and a recent study uses fluorescent determination in solid and liquid samples from agriculture, based on simultaneous extraction and fluorimetric labelling of $\mathrm{NH}_{3}$, followed by fluorescence measurement. The fluorimetric labelling reagent is the o-phthalaldehyde (OPA), and the reaction is based on the deprotonation of a $\mathrm{pH}$ indicator . 
410 As the $\mathrm{NH}_{3}$ molecule is not fluorescent by itself, quantifications are done using derivatization reactions like that used for the sensor in section 4.1.2.1. The signal recorded is the emission of photons after irradiation of the derivatization reagent. A trapping solution or new porous matrices like sol-gel or latexes have been developed to obtain a fluorescent signal from the non-fluorescent $\mathrm{NH}_{3}$ molecule. Thin films involve the reversible absorption and desorption of $\mathrm{NH}_{3}$ over periods of about one minute, that change the fluorescent signal of the polymer . Future developments could use such fluorescence sensitivity to measure $\mathrm{NH}_{3}$, and current applications of fluorescence-based sensors often measure $\mathrm{NH}_{3}$ concentrations down to about 5-50 ppm.

Another fluorescent sensor uses an array of seven chemical materials with fluorescent properties as the sensing elements. These kinds of materials can identify interactions between molecules such as $\mathrm{p}-\mathrm{p}$ molecular complex action, bond formation, acid-base interactions, physical adsorption, and Van der Waal forces. The sensor elements interact with specific gases that can change their fluorescent and photochemical properties, so that the change in their fluorescence can be detected. This approach has been successfully used in detecting $\mathrm{NH}_{3}$ once is dissolved in water, but could also be a good starting point to obtain rapid and inexpensive sensors for $\mathrm{NH}_{3}$ in air. Also, chemometrics could be used to calibrate or to discriminate contributions from other gases present in media, as it has been done with colour dye arrays .

\subsubsection{Photoacoustic based-sensors}

This optical technique involves the absorption of modulated laser radiation with a specific wavelength of $\sim 1530 \mathrm{~nm}$ for the $\mathrm{NH}_{3}$ molecule. The deactivation of the excited molecule via collisions is converted into a modulation frequency that induces acoustic waves that can be monitored with a low-noise microphone. The instrument layout consists of a laser source, a resonant photoacoustic (PA) cell, a microphone to monitor the sound waves and an 
electronic control module for laser modulation and signal processing . The PA spectroscopic gas detection technique has numerous advantages, making it a very promising candidate for $\mathrm{NH}_{3}$ detection in agriculture. PA provides continuous, selective and automatic measurements with outstanding long-term stability . Carbon dioxide $\left(\mathrm{CO}_{2}\right)$ and water vapour are the major potential interferences, but these can be addressed by using an isotopic ${ }^{13} \mathrm{CO}_{2}$ laser with a different wavelength to suppress the signals. Although PA is a very sensitive technique, it still lacks the robustness needed for use in agricultural environments because the sensors have a significant cross-sensitivity to nitrous oxide $\left(\mathrm{N}_{2} \mathrm{O}\right)$ and methane $\left(\mathrm{CH}_{4}\right)$. Moreover, electronic developments are needed to reduce the cost of the equipment (> $\$ 10,000$ ) in order to allow large-scale use of PA cells in commercial sensors. Most developments using this technique measure in the range of $0.1 \mathrm{ppm}$ to $100 \mathrm{ppm}$, so it could be used for monitoring $\mathrm{NH}_{3}$ in poultry houses, dairy wastewater lagoons and at property fence lines where the regulations mandate a maximum concentration of $0.5 \mathrm{ppm}$.

\subsection{Use of monitoring to support emission estimates}

\subsubsection{Emission factors}

Several approaches have been developed with different complexity levels to estimate $\mathrm{NH}_{3}$ emissions over large areas. The simplest method is collecting field data through surveys and multiplying each identified source by an emission factor (EF). For example, official estimates in several countries have been done using livestock numbers and amount of $\mathrm{N}$ fertilisers sold per year, multiplying these values by an average EF for each type of livestock and fertiliser . To achieve more accurate results, further developments added more variables to the models because the $\mathrm{NH}_{3}$ emission rate is affected by temperature, wind speed, air humidity, soil type, slurry $\mathrm{pH}$, among others . Specific EF have been developed for each individual emission source with information such as manure management system, housing facilities and season. The official $\mathrm{NH}_{3}$ emission estimates in China include sources like livestock excreta, fertiliser application, type of agricultural soil, nitrogen-fixing plants, crop residue compost, biomass burning, urine from rural populations, chemical industry, waste 
disposal and traffic. The EFs are disaggregated both spatially and temporally according to the climatic conditions and local practices across the country. The next step increasing complexity and accuracy is inferring $\mathrm{NH}_{3}$ emissions combining survey data with atmospheric dispersion models. This type of approach has demonstrated that is possible to estimate, with reasonable low bias, $\mathrm{NH}_{3}$ emissions from different sources across large areas with high resolution .

\subsubsection{Emission inventories}

Collecting data through farm surveys make the information independent from (subjective) expert judgment. The use of farm surveys to collect field data is an affordable method to populate $\mathrm{NH}_{3}$ inventories that are critical to evaluate policy changes in the agricultural sector and to verify compliance to international agreements. However, these inventories suffer from a number of inadequacies: i) poor spatial resolution, few measurements for large areas, leading generally to overestimations for non-agricultural zones and underestimations for emissions from farms; ii) poor temporal resolution, long term values underestimating the fertiliser application season; and iii) EFs are not specific for each source, average default values are used and several factors are left out of calculations .

\subsubsection{Monitoring networks and alternative approaches}

Higher spatial and temporal resolution and more reliable data are obtained adding measurements collected by sensors that are used to feed dispersion models. Large-area measurements are performed with commercial passive samplers, calibrated monthly against $\mathrm{NH}_{3}$ active sampling devices. An example using a combination of the dispersion model Fine Resolution $\mathrm{NH}_{3}$ Exchange (FRAME) and a network of passive diffusion samplers is the $\mathrm{NH}_{3}$ emission monitoring in the UK. FRAME describes the main atmospheric processes (emission, diffusion, chemistry and deposition) taking place in a column of air moving along straight-line trajectories following specified wind directions, taking into account also the transboundary chemical composition imported from other areas of Europe. Adding 
more variables to the calculations like the size and shape of the source, the locations of targets, the dynamics and magnitude of each source, the meteorological conditions, the background concentration and a set of passive diffusion sensors which integrate over a few hours to weekly periods helped improving the accuracy of the estimates of $\mathrm{NH}_{3}$ emissions from multiple small fields located near each other. Several passive and active samplers have been placed across countries to establish $\mathrm{NH}_{3}$ monitoring networks including: the UK (NAMN, National Ammonia Monitoring Network), the Netherlands (MAN, Measuring Ammonia in Nature), Switzerland, the United States (AMoN, Ammonia Monitoring Network) and Ireland. The main aim of the networks is to monitor national trends, to assess regional variability and to validate model calculations.

Traditional monitoring networks can be expensive, thus, a solution to poor temporal and spatial resolution can be crowdsourced information involving citizens in monitoring . Citizen science projects have become important data sources to scientists, and an attempt to estimate $\mathrm{NH}_{3}$ concentration from butterflies abundance has been published in a recent study measures such as lichen surveys .

\subsubsection{Communication technologies and monitoring}

511 The national inventories of $\mathrm{NH}_{3}$ emissions can be improved with further developments in low-cost portable devices based on the techniques mentioned in the previous Section 4.1. Nowadays, there is a class of wireless network technologies that enable low power consumption and wide area coverage (LPWANs - Low Power Wide Area Networks) such as Sigfox or LoRa technologies that fit the need of large-area deployments of $\mathrm{NH}_{3}$ sensors. Usually, these technologies have low-rate sporadic communications under unlicensed frequency bands, obtaining long distance links, normally $5 \mathrm{~km}$ in urban or over $25 \mathrm{~km}$ in rural or suburban areas. The use of these communication technologies together with sensitive sensors could be next upgrade to national inventories and $\mathrm{NH}_{3}$ monitoring giving a better temporal resolution. 


\section{Future $\mathrm{NH}_{3}$ sensing requirements}

523 There is great potential for $\mathrm{NH}_{3}$ sensing technology to contribute to both improving inventories and to the design of emission mitigation strategies. The next generation of sensors has to specifically monitor sources to avoid the harmful effects of $\mathrm{NH}_{3}$ and to help improve the efficiency in $\mathrm{N}$ use in the agroindustry. The deployment of appropriate sensors can support data collection to be used for:

528 i) Improving the formulation of livestock diets. Urea excretion and subsequent $\mathrm{NH}_{3}$ emissions increase with increased dietary crude protein concentration.

ii) Developing urea hydrolysis inhibitors, and investigating the effects of other mitigation strategies for $\mathrm{NH}_{3}$ emissions like soil $\mathrm{pH}$ control or irrigation after fertilising.

iii) Improving fertilising practices to maximize the $\mathrm{N}$ fertiliser value and improving

iv) Prompt decision making using real-time data, which is important for corrective actions manure management. The magnitude of $\mathrm{NH}_{3}$ losses depends on both weather and management practices so, improving the knowledge of the factors affecting $\mathrm{NH}_{3}$ emissions will help to develop better practices.

547 Ammonia emissions are indeed an important problem for society, where the dominant source is agriculture, creating not only an environmental problem but also nutrient losses 
549 that affect the efficiency of the agroindustry. Developments in $\mathrm{NH}_{3}$ monitoring can contribute

550 in several ways to mitigate these emissions by improving inventories to set international

551 targets and by forecasting future trajectories of the contribution from the agroindustry to

552 improve farm efficiency. Future monitoring systems built by simple and easy-to-deploy

553 sensors that sample and accumulate ammonia signals over representative periods (e.g. 1-4

554 weeks) can be used to scope farm ammonia performance in sensitive environments. These

555 systems do not need to be highly accurate but they do need to resolve individual farms or

556 significant sources e.g. passive directional samplers located up- and down- wind of intensive

557 livestock buildings. These systems should be deployable by non-specialists, who can send

558 samples to central laboratories for analysis and interpretation.

559

560

The current recommendations in the livestock industry are to avoid alkaline environments for ammonium ( $\mathrm{pH}>9.25)$, maintaining low temperature and avoiding air exchange in the superficial layer of manure ( $\mathrm{NH}_{3}$ vapour equilibrium). Nevertheless, every farm has its own characteristics in terms of climate, soil condition, type of manure, fertiliser applied, farm facilities and equipment, etc. So, weather data acquisition is essential for interpreting airquality data, and can be either measured or extracted from numerical weather prediction models. Tailored advice on manure and fertiliser management, and on livestock diets will have an important impact on nutrient balances in order to avoid unnecessary costs. There is also a need for activity data to be collected and reported alongside air quality data, so the data can be interpreted and attributed to specific activities.

571 Currently and despite advances in monitoring devices, direct measurements at each farmyard and plot are impractical due to the cost and labour involved. Additional research is needed to extend cost-effective monitoring to large areas. An important contribution could be the use of wireless technology to connect sensors to make large deployments without

575 human intervention during long periods of time. In addition, the air produced in agriculture environments is a mixture of a large number of gases plus relatively high moisture content. 
577 Some of the currently available sensors are prone to have severe interferences since they

578 are sensitive to water vapour and other gases than $\mathrm{NH}_{3}$. Therefore there is a need for new

579 measurement methods customized for agriculture environments, where interferences are

580 correctly calibrated. Future sensors should provide multivariate signals about the target

581 compounds and interferences, for the application of statistical modelling.

582

583

\section{Conclusions}

584 Agricultural emissions of $\mathrm{NH}_{3}$ are primarily associated with livestock production where the losses are notably high and there is a pressing need for new developments so that farmers monitor and control $\mathrm{NH}_{3}$ emissions from fertiliser use. New user-friendly sensors are needed with enough sensitivity for monitoring low concentration (ppb). For this purpose, spectroscopic sensors can provide appropriately selective and sensitive measurements because the spectra from these sensors usually include information that allows interferences to be removed or reduced. Also, spectroscopic sensors can be automated and miniaturized to create low-cost sensors that offer real-time data for day-to-day decisions on ammonia control. The key improvements required in electrochemical sensors are better sensitivity and the development of sensing materials that work at room temperature. Photoacoustic sensors require new advances in electronics to lower their cost. It can be concluded that there is an immediate need of sensors that are more sensitive, selective, low-cost and user-friendly. Sensors must be capable of dealing with the high interferences arising in agricultural environments. Above all, there is an urgent need for new sensors to support the optimal use of $\mathrm{N}$ in agriculture so that nutrient pollution in the troposphere is minimised.

\section{Acknowledgment}

We thank the UUKi Rutherford Fund Strategic Partner Grants and the UK Department for 
603

604

605

606

607

608

609

610

611

612

613

614

615

616

617

618

619

620

621

622

623

624

625

the financial contribution of the Argentinean National Research Council (CONICET), Universidad Nacional del Sur, Lancaster University and UK Environmental Agency.

\section{Conflict of interest}

None.

\section{Disclaimer}

The views expressed are those of the authors and not necessarily those of the UK Environment Agency.

\section{References}

Ates, M., 2013. A review study of (bio) sensor systems based on conducting polymers. J Materials Science and Engineering 33(4): 1853-1859.

ATSDS, 2004. Agency for Toxic Substances and Disease Registry . Public health statement - Ammonia CAS 7664-41-7: 1-7.

Ayres, J., 2009. Long-term exposure to air pollution: effect on mortality. Didcot: Committee on the Medical Effects of Air Pollutants: 1-187.

Azcarate, S., A. de Araújo Gomes, A. M. de la Peña and H. C. Goicoechea, 2018. Modeling second-order data for classification issues: Data characteristics, algorithms, processing procedures and applications. TrAC Trends in Analytical Chemistry(107): 151-168.

Bai, H. and G. Shi, 2007. Gas sensors based on conducting polymers. Sensors 7(3): 267307. 
626 Baskar, C., N. Nesakumar, J. B. B. Rayappan and M. Doraipandian, 2017. A low power 627 ammonia sensor node embedded with a light weight non-linear analytics. Sensors Actuators A: Physical 263: 357-362.

629

Battye, R., W. Battye, C. Overcash and S. Fudge, 1994. Development and selection of 630 ammonia emission factors. EPA, US. U. EPA. US, Atmospheric Research and Exposure Assessments Laboratory.

Behera, S. N. and M. Sharma, 2010. Investigating the potential role of ammonia in ion chemistry of fine particulate matter formation for an urban environment. Science of the Total Environment 408(17): 3569-3575.

Bell, M., C. Flechard, Y. Fauvel, C. Häni, J. Sintermann, M. Jocher, H. Menzi, A. Hensen and A. Neftel, 2017. Ammonia emissions from a grazed field estimated by miniDOAS measurements and inverse dispersion modelling. Atmospheric Measurement Techniques 10(5): 1875-1892.

Bhopate, D., K. Kim, P. Mahajan, A. Gore, S. Patil and S. Majhi, 2017. Fluorescent 640 chemosensor for quantitation of multiple atmospheric gases. Journal of Nanomed Nanotechnology 8(2): 1-9.

Bicudo, J. R., C. L. Tengman, L. D. Jacobson and J. E. Sullivan, 2000. Odor, hydrogen sulfide and ammonia emissions from swine farms in Minnesota. Proceedings of the Water Environment Federation 2000(3): 589-608.

645

Bittman, S., M. Dedina, C. Howard, O. Oenema and M. Sutton, 2014. Options for ammonia 646 mitigation: Guidance from the UNECE Task Force on Reactive Nitrogen, NERC/Centre for

647 Ecology \& Hydrology.

648 Bittman, S. and R. Mikkelsen, 2009. Ammonia emissions from agricultural operations: 649 livestock. Better Crops 93(1): 28-31. 
650 Bor, M., J. E. Vidler and U. Roedig, 2016. LoRa for the Internet of Things. Proceedings of 651 the 2016 International Conference on Embedded Wireless Systems and Networks (EWSN '16), TU Graz, Austria.

653

Bor, M. C., U. Roedig, T. Voigt and J. M. Alonso, 2016. Do LoRa low-power wide-area 654 networks scale? Proceedings of the 19th ACM International Conference on Modeling, Analysis and Simulation of Wireless and Mobile Systems, ACM.

Bouwman, A., D. Lee, W. Asman, F. Dentener, K. Van Der Hoek and J. Olivier, 1997. A global high-resolution emission inventory for ammonia. Global Biogeochemical Cycles 11(4): $561-587$.

Brigden, K. and R. Stringer, 2000. Ammonia and urea production: Incidents of ammonia 660 release from the Profertil urea and ammonia facility, Bahia Blanca, Argentina 2000. Greenpeace reports. S. p. A. Tour. Exeter UK, Greenpeace Research Laboratories, Department of Biological Sciences, University of Exeter, Exeter, UK: 1-13.

Brink, C. and H. Van Grinsven, 2011. Costs and benefits of nitrogen in the environment. The European Nitrogen Assessment: Sources, Effects and Policy Perspectives. M. Sutton, C. M. Howard, J. W. Erisman et al.: 513-540.

Cape, J., L. Van der Eerden, L. Sheppard, I. Leith and M. Sutton, 2009. Evidence for changing the critical level for ammonia. Environmental Pollution 157(3): 1033-1037.

Carozzi, M., R. M. Ferrara, M. Acutis and R. G., 2012. Dynamic of ammonia emission from urea spreading in Po Valley (Italy): relationship with nitrogen compounds in the soil. Proceeding of 17th International Nitrogen Workshop. Wexford, 26-29 June 2012.

671 Changwen, D., W. Jiao, Z. Zijun, S. Yazhen and Z. Jianmin, 2015. In situ measurement of ammonia concentration in soil headspace using Fourier transform mid-infrared photoacoustic spectroscopy. Journal of Pedosphere 25(4): 605-612.

674 Chen, X., L. Lin, P. Li, Y. Dai and X. Wang, 2004. Fluorescent response of sol-gel derived ormosils for optical ammonia sensing film. Analytica Chimica Acta 506(1): 9-15. 
676 Chen, Y., Q. Zhang and D. Petkau, 2001. Evaluation of different techniques for liquid 677 manure application on grassland. Applied Engineering in Agriculture 17(4): 489.

678 Cho, Y. B., S. H. Jeong, H. Chun and Y. S. Kim, 2018. Selective colorimetric detection of dissolved ammonia in water via modified Berthelot's reaction on porous paper. Sensors 680 Actuators B: Chemical 256: 167-175.

Darwish, A. M., S. Wilson, A. Balckwell, K. Taylor, S. S. Sarkisov, D. N. Patel and B. Koplitz, 2015. Ammonia sensor based on polymer-inorganic nano-composite thin film upconversion light emitter prepared by double-beam pulsed laser deposition. American Journal of Materials Science 5(3A): 8-15.

Das, P., J.-H. Sa, K.-H. Kim and E.-C. Jeon, 2009. Effect of fertilizer application on ammonia emission and concentration levels of ammonium, nitrate, and nitrite ions in a rice field. Environmental monitoring and assessment 154(1-4): 275-282.

Dasari, B., W. Taube, P. Agarwal, M. Rajput, A. Kumar and J. Akhtar, 2015. Room 689 Temperature Single Walled Carbon Nanotubes (SWCNT) Chemiresistive Ammonia Gas Sensor Sensors and Transducers 190(7): 24-30.

691

Daughton, C., J. Cantor, M. Jones and R. Sakaji, 1982. Chapter III - Ammonia determination

Quantitation of oil shale wastewater quality. A manual of analytical methods. C. Daughton. Berkeley, USA, University of California.

DEFRA, 2018. Code of Good Agricultural Practice (COGAP) for Reducing Ammonia Emissions. London TW9 4DU, Department for Environment Food \& Rural Affairs, UK Government.

Denmead, O., J. Freney and J. Simpson, 1983. Dynamics of ammonia volatilization during furrow irrigation of maize. Soil Science Society of America Journal 47(3)

Denmead, O., J. Simpson and J. Freney, 1974. Ammonia flux into the atmosphere from a grazed pasture. Science 185(4151): 609-610. 
701

702

703

704

705

706

707

708

709

710

711

712

713

714

715

716

717

718

719

720

721

722

723

724

Dewey, C. E., B. Cox and J. Leyenaar, 2000. Measuring ammonia concentrations in the barn using the Draeger (TM) and pHydrion (TM) tests. Journal of Swine Health and Production 8(3): 127-131.

Djambazov, G. and K. Pericleous, 2015. Modelled atmospheric contribution to nitrogen eutrophication in the English Channel and the southern North Sea. Atmospheric Environment 102: 191-199.

Dore, A., D. Carslaw, C. Braban, M. Cain, C. Chemel, C. Conolly, R. Derwent, S. Griffiths, J. Hall and G. Hayman, 2015. Evaluation of the performance of different atmospheric chemical transport models and inter-comparison of nitrogen and sulphur deposition estimates for the UK. Atmospheric Environment 119: 131-143.

Doyle, B., T. Cummins, C. Augustenborg and J. Aherne, 2014. Ambient Atmospheric Ammonia in Ireland, 2013-2014. Environmental Protection Agency of Ireland, report(193).

Dumitras, D., D. Dutu, C. Matei, A. Magureanu, M. Petrus and C. Popa, 2007. Laser photoacoustic spectroscopy: principles, instrumentation, and characterization. Journal of Optoelectronics Advanced Materials 9(12): 3655.

EAA, 2014. European Environment Agency. Ammonia (NH3) emissions. European Environment Agency Retrieved 02/01/2019, 2019, from http://www.eea.europa.eu/data-and$\underline{\text { maps/indicators/eea-32-ammonia-nh3-emissions-1/assessment-4. }}$

EAA, 2016. National Emission Ceilings Directive. European Environment Agency. Denmark, European Environment Agency.

EPA, 2016. U.S. Environmental Protection Agency. Toxicological Review of Ammonia (EPA/635/R-16/163Fa ). Integrated Risk Information System. Washington, DC.

EUROSTAT, 2016. Agriculture, forestry and fishery statistics. Belgium, European Union, 2016. 
725 Fan, H., Z. Peng, H. Yang and K. Zhou, 2016. A new cataluminescence-based gas sensor 726 for simultaneously discriminating benzene and ammonia. Analytical Methods 8(6): 12577271264.

728 Feng, L., C. J. Musto, J. W. Kemling, S. H. Lim, W. Zhong and K. S. Suslick, 2010. 729 Colorimetric sensor array for determination and identification of toxic industrial chemicals. 730 Analytical Chemistry 82(22): 9433-9440.

731 Fenn, L. and L. Hossner, 1985. Ammonia volatilization from ammonium or ammonium732 forming nitrogen fertilizers. Advances in Soil Science : 123-169. Ferrara, R. M., M. Carozzi, P. Di Tommasi, D. D. Nelson, G. Fratini, T. Bertolini, V. Magliulo, M. Acutis and G. Rana, 2016. Dynamics of ammonia volatilisation measured by eddy covariance during slurry spreading in north Italy. Agriculture, Ecosystems Environment 219: $1-13$.

Fitzpatrick, R. B., 2004. Haz-Map: information on hazardous chemicals and occupational diseases. Medical Reference Services Quarterly 23(2): 49-56.

Fournier, N., V. A. Pais, M. A. Sutton, K. J. Weston, U. Dragosits, S. Y. Tang and J. Aherne, 2002. Parallelisation and application of a multi-layer atmospheric transport model to quantify dispersion and deposition of ammonia over the British Isles. Environmental Pollution 116(1): 95-107.

Ganiga, M. and J. Cyriac, 2016. FRET based ammonia sensor using carbon dots. Sensors and Actuators B: Chemical 225: 522-528.

García, M. S., R. Timmis, N. Van Dijk, J. Whyatt, I. Leith, S. Leeson, C. Braban, L. Sheppard, M. Sutton and Y. Tang, 2017. Directional passive ambient air monitoring of ammonia for fugitive source attribution; a field trial with wind tunnel characteristics. Atmospheric Environment 167: 576-585.

Goebes, M. D., R. Strader and C. Davidson, 2003. An ammonia emission inventory for fertilizer application in the United States. Atmospheric Environment 37(18): 2539-2550. 
751 Guimard, N. K., N. Gomez and C. E. Schmidt, 2007. Conducting polymers in biomedical 752 engineering. Progress in Polymer Science 32(8-9): 876-921.

753 Guthrie, S., S. Giles, F. Dunkerley, H. Tabaqchali, A. Harshfield, B. Ioppolo and C. Manville, 754 2018. The impact of ammonia emissions from agriculture on biodiversity. JOURNAL?

755

Harper, L., V. Catchpoole, R. Davis and K. Weir, 1983. Ammonia Volatilization: Soil, Plant, and Microclimate Effects on Diurnal and Seasonal Fluctuations 1. Agronomy Journal 75(2): 212-218.

Harper, L. A., R. R. Sharpe and T. B. Parkin, 2000. Gaseous nitrogen emissions from anaerobic swine lagoons: Ammonia, nitrous oxide, and dinitrogen gas. Journal of Environmental Quality 29(4): 1356-1365.

Horswill, P., O. O'Sullivan, G. K. Phoenix, J. A. Lee and J. R. Leake, 2008. Base cation depletion, eutrophication and acidification of species-rich grasslands in response to longterm simulated nitrogen deposition. Environmental Pollution 155(2): 336-349.

Hu, J., L. Zhang and Y. Lv, 2018. Recent advances in cataluminescence gas sensor: Materials and methodologies. Applied Spectroscopy Reviews (VOL?): 1-19.

Huang, X., Y. Song, M. Li, J. Li, Q. Huo, X. Cai, T. Zhu, M. Hu and H. Zhang, 2012. A high-resolution ammonia emission inventory in China. Global Biogeochemical Cycles 26(1).

Huszár, H., A. Pogány, Z. Bozóki, Á. Mohácsi, L. Horváth and G. Szabó, 2008. Ammonia monitoring at ppb level using photoacoustic spectroscopy for environmental application. Sensors Actuators B: Chemical 134(2): 1027-1033.

Ibanez, J. G., M. E. Rincón, S. Gutierrez-Granados, M. h. Chahma, O. A. Jaramillo-Quintero and B. A. Frontana-Uribe, 2018. Conducting polymers in the fields of energy, environmental remediation, and chemical-chiral sensors. Chemical reviews 118(9): 4731-4816.

Jalalvand, A. R., M. Roushani, H. C. Goicoechea, D. N. Rutledge and H.-W. Gu, 2018. MATLAB in electrochemistry: A review. Talanta. INCOMPLETE 
Jin, Z., Y. Su and Y. Duan, 2001. Development of a polyaniline-based optical ammonia sensor. Sensors and Actuators B: Chemical 72(1): 75-79.

Kelleghan, D. B., E. T. Hayes, M. Everard and T. P. Curran, 2019. Mapping ammonia risk on sensitive habitats in Ireland. Science of the Total Environment 649: 1580-1589.

Khan, E. A., 2016. Dap-1 ammonia tank explosion: safety and security concerns in chemical process plant in Bangladesh. International Journal of Petrochemical Science \& Engineering 1(1): 10-11.

Khan, M. A., F. Qazi, Z. Hussain, M. U. Idrees, S. Soomro and S. Soomro, 2017. Recent Trends in Electrochemical Detection of NH3, H2S and NOx Gases. International Journal of Electrochemical Science 12(3): 1711-1733.

Koerkamp, P. G., J. Metz, G. Uenk, V. Phillips, M. Holden, R. Sneath, J. Short, R. White, J. Hartung and J. Seedorf, 1998. Concentrations and emissions of ammonia in livestock buildings in Northern Europe. Journal of Agricultural Engineering Research 70(1): 79-95.

Lakowicz, J. R., 1999. Instrumentation for fluorescence spectroscopy. Principles of fluorescence spectroscopy, Springer: 25-61.

Lau, K. T., S. Edwards and D. Diamond, 2004. Solid-state ammonia sensor based on 792 Berthelot's reaction. Sensors and Actuators B: Chemical 98(1): 12-17.

Lavrsen Kure, J., J. Krabben, S. Vilms Pedersen, M. Carozzi and S. Sommer, 2018. An Assessment of Low-Cost Techniques to Measure Ammonia Emission from Multi-Plots: A Case Study with Urea Fertilization. Agronomy Journal 8(11): 245.

Le Maout, P., J.-L. Wojkiewicz, N. Redon, C. Lahuec, F. Seguin, L. Dupont, S. Mikhaylov, Y. Noskov, N. Ogurtsov and A. Pud, 2018. Polyaniline nanocomposites based sensor array for breath ammonia analysis. Portable e-nose approach to non-invasive diagnosis of chronic kidney disease. Sensors and Actuators B: Chemical 274: 616-626. 
801 Detection of ammonia based on a novel fluorescent artificial nose and pattern recognition. 802 Atmospheric Pollution Research 7(3): 431-437.

Li, H., C. Zhang and H. Xin, 2015. Performance of an infrared Photoacoustic single gas analyzer in measuring ammonia from poultry houses. Applied Engineering in Agriculture 805 31(3): 471-477.

Li, X., X. Li, Z. Li, J. Wang and J. Zhang, 2017. WS2 nanoflakes based selective ammonia sensors at room temperature. Sensors Actuators B: Chemical 240: 273-277.

Lolkema, D., H. Noordijk, A. Stolk, R. Hoogerbrugge, M. van Zanten and W. van Pul, 2015.

The measuring ammonia in nature (MAN) network in the Netherlands. Biogeosciences 12(16): 5133-5142.

Loubet, B., M. Carozzi, P. Voylokov, J.-P. Cohan, R. Trochard and S. Génermont, 2018.

812 Evaluation of a new inference method for estimating ammonia volatilisation from multiple agronomic plots. Biogeosciences 15(11): 3439.

Maciak, E. and T. Pustelny, 2013. An optical ammonia (NH3) gas sensing by means of $\mathrm{Pd} / \mathrm{CuPc}$ interferometric nanostructures based on white light interferometry. Sensors Actuators B: Chemical 189: 230-239.

817 Manap, H., G. Dooly, S. O'Keeffe and E. Lewis, 2011. Cross-sensitivity evaluation for 818 ammonia sensing using absorption spectroscopy in the UV region. Sensors Actuators B: Chemical 154(2): 226-231.

McGinn, S., H. Janzen, T. Coates, K. Beauchemin and T. Flesch, 2016. Ammonia emission from a beef cattle feedlot and its local dry deposition and re-emission. Journal of

822 Environmental Quality 45(4): 1178-1185.

823 Meng, Z.-Y., X.-B. Xu, T. Wang, X.-Y. Zhang, X.-L. Yu, S.-F. Wang, W.-L. Lin, Y.-Z. Chen, 824 Y.-A. Jiang and X.-Q. An, 2010. Ambient sulfur dioxide, nitrogen dioxide, and ammonia at 
825 ten background and rural sites in China during 2007-2008. Atmospheric Environment 44(2122): 2625-2631.

Mikkelsen, R., 2009. Ammonia emissions from agricultural operations: fertilizer. Better Crops 93(4): 9-11.

Miles, D., 2008. Vertical stratification of ammonia in a broiler house. Journal of Applied Poultry Research 17(3): 348-353.

Mills, A., L. Wild and Q. Chang, 1995. Plastic colorimetric film sensors for gaseous ammonia. Microchimica Acta 121(1-4): 225-236.

Misselbrook, T., S. Gilhespy, L. Cardenas, J. Willimas and U. Dragosits, 2015. Inventory of Ammonia Emissions from UK, Agriculture. 2014. UK., DEFRA. Department for Environment, Food and Rural Affairs.

Moum, S. G., W. Seltzer and T. M. Goldhaft, 1969. A simple method of determining concentrations of ammonia in animal quarters. Poultry Science 48(1): 347-348.

Mount, G. H., B. Rumburg, J. Havig, B. Lamb, H. Westberg, D. Yonge, K. Johnson and R. Kincaid, 2002. Measurement of atmospheric ammonia at a dairy using differential optical absorption spectroscopy in the mid-ultraviolet. Atmospheric Environment 36(11): 1799-1810.

Mukhtar, S., A. Rose, S. Capareda, C. Boriack, R. Lacey, B. Shaw and C. Parnell, 2003. Assessment of ammonia adsorption onto Teflon and LDPE tubing used in pollutant stream conveyance.

Naseem, S. and A. J. King, 2018. Ammonia production in poultry houses can affect health of humans, birds, and the environment-techniques for its reduction during poultry production. Environmental Science Pollution Research: 1-25.

$847 \mathrm{Ni}$, J.-Q. and A. J. Heber, 1998. Sampling and measurement of ammonia concentration at animal facilities-A review. 2001 ASAE Annual Meeting, American Society of Agricultural and Biological Engineers. 
$850 \mathrm{Ni}$, J.-Q. and A. J. Heber, 2008. Sampling and measurement of ammonia at animal facilities.

851 Advances in Agronomy 98: 201-269.

852 NRC, 2003. National Research Council. Air emissions from animal feeding operations: 853 Current knowledge, future needs. National Academies Press.

854 Oenema, O., H. Witzke, Z. Klimont, J. Lesschen and G. Velthof, 2009. Integrated assessment of promising measures to decrease nitrogen losses from agriculture in EU-27. Agriculture, Ecosystems Environment 133(3-4): 280-288.

Pan, B., S. K. Lam, A. Mosier, Y. Luo and D. Chen, 2016. Ammonia volatilization from synthetic fertilizers and its mitigation strategies: a global synthesis. Agriculture, Ecosystems Environment 232: 283-289.

Pavlovic, R. T., U. Nopmongcol, Y. Kimura and D. T. Allen, 2006. Ammonia emissions, concentrations and implications for particulate matter formation in Houston, TX. Atmospheric Environment 40: 538-551.

Phan, N.-T., K.-H. Kim, Z.-H. Shon, E.-C. Jeon, K. Jung and N.-J. Kim, 2013. Analysis of ammonia variation in the urban atmosphere. Atmospheric Environment 65: 177-185. P. Robarge, 2011. Passive ammonia monitoring in the United States: Comparing three different sampling devices. Journal of Environmental Monitoring 13(11): 3156-3167.

Pushkarsky, M., M. Webber and C. Patel, 2003. Ultra-sensitive ambient ammonia detection using CO 2-laser-based photoacoustic spectroscopy. Applied Physics B 77(4): 381-385.

870 Reche, C., M. Viana, M. Pandolfi, A. Alastuey, T. Moreno, F. Amato, A. Ripoll and X. Querol, 871 2012. Urban NH3 levels and sources in a Mediterranean environment. Atmospheric 872 Environment 57: 153-164. 
873 Reidy, B., B. Rhim and H. Menzi, 2008. A new Swiss inventory of ammonia emissions from

874 agriculture based on a survey on farm and manure management and farm-specific model 875 calculations. Atmospheric Environment 42(14): 3266-3276.

876 Rosenstock, T. S., E. Diaz-Pines, P. Zuazo, G. Jordan, M. Predotova, P. Mutuo, S. 877 Abwanda, M. Thiong'o, A. Buerkert and M. C. Rufino, 2013. Accuracy and precision of 878 photoacoustic spectroscopy not guaranteed. Global Change Biology 19(12): 3565-3567.

879 Rostami, M., S. Monaco, D. Sacco, C. Grignani and E. Dinuccio, 2015. Comparison of 880 ammonia emissions from animal wastes and chemical fertilizers after application in the soil. 881 International Journal of Recycling of Organic Waste in Agriculture 4(2): 127-134.

882 RoTAP., 2012. Review of Transboundary Air Pollution (RoTAP): Acidification, 883 Eutrophication, Ground Level Ozone and Heavy Metals in the UK: Summary for Policy 884 Makers, Centre for Ecology \& Hydrology.

885 Sather, M. E., J. Mathew, N. Nguyen, J. Lay, G. Golod, R. Vet, J. Cotie, T. Hertel, E. Aaboe 886 and R. Callison, 2008. Baseline ambient gaseous ammonia concentrations in the Four Corners area and eastern Oklahoma, USA. Journal of Environmental Monitoring 10(11): 1319-1325.

Schilt, S., L. Thévenaz, M. Niklès, L. Emmenegger and C. Hüglin, 2004. Ammonia 890 monitoring at trace level using photoacoustic spectroscopy in industrial and environmental applications. Spectrochimica Acta Part A: Molecular and Biomolecular Spectroscopy 60(14): 3259-3268.

Schroeck, A. M., V. Gaube, E. Haas and W. Winiwarter, 2019. Estimating nitrogen flows of agricultural soils at a landscape level-A modelling study of the Upper Enns Valley, a longterm socio-ecological research region in Austria. Science of The Total Environment 665: 275-289.

Shankar, P. and J. B. B. Rayappan, 2015. Gas sensing mechanism of metal oxides: The role of ambient atmosphere, type of semiconductor and gases-A review. Sci. Lett. J 4: 126. 
900 Hussain, 2018. Ammonia production in the poultry houses and its harmful effects. 901 International Journal of Veterinary Sciences and Animal Husbandry 3(4): 30-33. N. van Dijk and D. Fowler, 2011. Dry deposition of ammonia gas drives species change faster than wet deposition of ammonium ions: evidence from a long-term field manipulation. Global Change Biology 17(12): 3589-3607.

Sigrist, M. W., 2015. Mid-infrared laser-spectroscopic sensing of chemical species. Journal of Advanced Research 6(3): 529-533.

Silva, S. O., R. Magalhães, M. Marques and O. Frazão, 2016. New advances in fiber cavity ring-down technology. Optics Laser Technology 78: 115-119.

Singles, R., M. Sutton and K. Weston, 1998. A multi-layer model to describe the atmospheric transport and deposition of ammonia in Great Britain. Atmospheric Environment 32(3): 393399.

Sintermann, J., C. Ammann, U. Kuhn, C. Spirig, R. Hirschberger, A. Gärtner and A. Neftel, 2011. Determination of field scale ammonia emissions for common slurry spreading practice with two independent methods. Atmospheric Measurement Techniques 4(9): 1821-1840.

Sommer, S. G., J. E. Olesen and B. T. Christensen, 1991. Effects of temperature, wind speed and air humidity on ammonia volatilization from surface applied cattle slurry. The Journal of Agricultural Science 117(1): 91-100.

Šraj, L. O. C., M. I. G. Almeida, S. E. Swearer, S. D. Kolev and I. D. McKelvie, 2014. Analytical challenges and advantages of using flow-based methodologies for ammonia determination in estuarine and marine waters. TrAC Trends in Analytical Chemistry 59: 8392.

923 Strömberg, N. and S. Hulth, 2001. An ammonium selective fluorosensor based on the principles of coextraction. Analytica Chimica Acta 443(2): 215-225. 
925 Sun, K., L. Tao, D. J. Miller, M. A. Zondlo, K. B. Shonkwiler, C. Nash and J. M. Ham, 2015.

926 Open-path eddy covariance measurements of ammonia fluxes from a beef cattle feedlot.

927 Agricultural and Forest Meteorology 213: 193-202.

928 Sutton, M., Y. Tang, B. Miners and D. Fowler, 2001. A new diffusion denuder system for 929 long-term, regional monitoring of atmospheric ammonia and ammonium. Water, Air and Soil 930 Pollution: Focus 1(5-6): 145-156.

931 Tang, Y., J. Cape and M. Sutton, 2001. Development and types of passive samplers for 932 monitoring atmospheric NO2 and NH3 concentrations. The Scientific World Journal 1: 513933529.

934 Tang, Y. S., U. Dragosits, N. van Dijk, L. Love, I. Simmons and M. A. Sutton, 2009. 935 Assessment of ammonia and ammonium trends and relationship to critical levels in the UK National Ammonia Monitoring Network (NAMN). Atmospheric Ammonia, Springer: 187-194.

937 Tang, Z., J. Yang, J. Yu and B. Cui, 2010. A colorimetric sensor for qualitative discrimination 938 and quantitative detection of volatile amines. Sensors 10(7): 6463-6476.

939 Tanguy, N. R., M. Thompson and N. Yan, 2018. A review on advances in application of 940 polyaniline for ammonia detection. Sensors and Actuators B: Chemical 257: 1044-1064.

941 Tavoli, F. and N. Alizadeh, 2013. Optical ammonia gas sensor based on nanostructure dye942 doped polypyrrole. Sensors and Actuators B: Chemical 176: 761-767.

943 The Royal Society, 2018. The impact of ammonia emissions from agriculture on biodiversity. 944 RAND Europe. S. Guthrie, S. Giles, F. Dunkerley et al. Cambridge, UK.

945 Thöni, L., P. Brang, S. Braun, E. Seitler and B. Rihm, 2004. Ammonia monitoring in 946 Switzerland with passive samplers: patterns, determinants and comparison with modelled 947 concentrations. Environmental Monitoring and Assessment 98(1-3): 93-107.

948 Timmer, B., W. Olthuis and A. Van Den Berg, 2005. Ammonia sensors and their 949 applications—a review. Sensors Actuators B: Chemical 107(2): 666-677. 
950 Toda, K., J. Li and P. K. Dasgupta, 2006. Measurement of ammonia in human breath with a

951 liquid-film conductivity sensor. Analytical chemistry 78(20): 7284-7291.

952 UK_Government, 2019. The Environmental Permitting (England and Wales) Regulations. 953 from http://www.legislation.gov.uk/.

954 United Nations, E. a. S. C., 2014. Convention on Long-range Transboundary Air Pollution:

955 Guidance document on preventing and abating ammonia emissions from agricultural 956 sources.

957 USHHS, 2004. U.S. Department of Health and Human Services. Toxicological Profile For 958 Ammonia. Agency for Toxic Substances and Disease Registry. P. H. Service. US, U.S. 959 DEPARTMENT OF HEALTH AND HUMAN SERVICES.

960 Vaddella, V., P. Ndegwa, H. Joo and J. J. J. o. e. q. Ullman, 2010. Impact of separating dairy 961 cattle excretions on ammonia emissions. 39(5): 1807-1812.

962 Valente, I. M., H. M. Oliveira, C. D. Vaz, R. M. Ramos, A. J. Fonseca, A. R. Cabrita and J. A. 963 Rodrigues, 2017. Determination of ammonia nitrogen in solid and liquid high-complex 964 matrices using one-step gas-diffusion microextraction and fluorimetric detection. Talanta 965 167: 747-753.

966 Van Damme, M., L. Clarisse, S. Whitburn, J. Hadji-Lazaro, D. Hurtmans, C. Clerbaux and 967 P.-F. Coheur, 2018. Industrial and agricultural ammonia point sources exposed. Nature 968 564(7734): 99.

969 Van der Heyden, C., E. Brusselman, E. Volcke and P. Demeyer, 2016. Continuous 970 measurements of ammonia, nitrous oxide and methane from air scrubbers at pig housing 971 facilities. Journal of Environmental Management 181: 163-171.

972 Vantieghem, P., D. Maes, A. Kaiser and T. Merckx, 2017. Quality of citizen science data and 973 its consequences for the conservation of skipper butterflies (Hesperiidae) in Flanders 974 (northern Belgium). Journal of Insect Conservation 21(3): 451-463. 
975 Velthof, G., C. Van Bruggen, C. Groenestein, B. De Haan, M. Hoogeveen and J. Huijsmans, 976 2012. A model for inventory of ammonia emissions from agriculture in the Netherlands. 977 Atmospheric Environment 46: 248-255.

978 Vieno, M., M. Heal, S. Hallsworth, D. Famulari, R. Doherty, A. Dore, Y. Tang, C. Braban, D. 979 Leaver and M. Sutton, 2014. The role of long-range transport and domestic emissions in 980 determining atmospheric secondary inorganic particle concentrations across the UK. 981 Atmospheric Chemistry Physics 14(16): 8435-8447.

982 Waldrip, H., N. Cole and R. Todd, 2015. Nitrogen sustainability and beef cattle feedyards: II. 983 Ammonia emissions. The Professional Animal Scientist 31(5): 395-411.

984 Wang, S., J. Nan, C. Shi, Q. Fu, S. Gao, D. Wang, H. Cui, A. Saiz-Lopez and B. Zhou, 2015. 985 Atmospheric ammonia and its impacts on regional air quality over the megacity of Shanghai, 986 China. Scientific Reports 5: 15842.

987 Wathes, C. M., T. G. Demmers and H. Xin, 2003. Ammonia concentrations and emissions in 988 livestock production facilities: guidelines and limits in the USA and UK. 2003 ASAE Annual 989 Meeting, American Society of Agricultural and Biological Engineers.

Webber, M. E., T. MacDonald, M. B. Pushkarsky, C. K. N. Patel, Y. Zhao, N. Marcillac and 991 F. M. Mitloehner, 2005. Agricultural ammonia sensor using diode lasers and photoacoustic spectroscopy. Measurement Science Technology 16(8): 1547.

Weeser, B., J. S. Kroese, S. Jacobs, N. Njue, Z. Kemboi, A. Ran, M. Rufino and L. Breuer, 994 2018. Citizen science pioneers in Kenya-A crowdsourced approach for hydrological monitoring. Science of The Total Environment 631: 1590-1599.

Wilson, L., P. Bacon, J. Bull, U. Dragosits, T. Blackall, T. Dunn, K. Hamer, M. Sutton and S. Wanless, 2004. Modelling the spatial distribution of ammonia emissions from seabirds in the UK. Environmental Pollution 131(2): 173-185. 
Wolseley, P. A., P. W. James, M. R. Theobald and M. A. Sutton, 2006. Detecting changes in

1000 epiphytic lichen communities at sites affected by atmospheric ammonia from agricultural 1001 sources. The Lichenologist 38(2): 161-176.

1002 Zhang, D., Z. Wu, P. Li, X. Zong, G. Dong and Y. Zhang, 2018. Facile fabrication of 1003 polyaniline/multi-walled carbon nanotubes/molybdenum disulfide ternary nanocomposite and 1004 its high-performance ammonia-sensing at room temperature. Sensors and Actuators B: 1005 Chemical 258: 895-905.

1006 Zhang, Y. and L.-T. Lim, 2018. Colorimetric array indicator for NH3 and CO2 detection. 1007 Sensors and Actuators B: Chemical 255: 3216-3226.

1008 Zhao, L., R. Manuzon, M. Darr, H. Keener, A. J. Heber and J.-Q. Ni, 2009. Ammonia 1009 emissions from a commercial poultry manure composting facility. Livestock Environment VIII,

101031 August-4 September 2008, Iguassu Falls, Brazil, American Society of Agricultural and 1011 Biological Engineers. 